\title{
Mytilus galloprovincialis as Mussel Watch for Butyltins, Tin, Copper and Zinc Contamination, from Antifouling Paint Particles, in West Algerian Coastal Waters
}

\author{
Zoubida El Hadj $^{1 *}$, Zitouni Boutiba ${ }^{1}$, Boucif Belbachir ${ }^{2}$ \\ ${ }^{1}$ Laboratoire Réseau de Surveillance Environnementale, Faculté des Sciences, Université d'Oran, Oran, Algeria; ${ }^{2}$ Laboratoire de \\ Chimie des Polymères, Faculté des Sciences, Université d'Oran, Oran, Algeria. \\ Email: ${ }^{*}$ manelasmaa@yahoo.fr
}

Received March 24 $4^{\text {th }}, 2012$; revised April 29 th $^{\text {th }}$ 2012; accepted June $5^{\text {th }}, 2012$

\begin{abstract}
Butyltin compounds (BTs) including tributyltin (TBT) and its degradation product (DBT) and concentrations of heavy metals ( $\mathrm{Sn}, \mathrm{Cu}$ and $\mathrm{Zn}$ ) were determined in mussels (Mytilus galloprovencialis) collected from some West Algerian harbours. BTs were detected in all the mussels. Quantification of BTs and heavy metals was carried respectively by Gas Chromatography coupled with Mass Spectrometer (GC-MS) and Atomic Absorption Spectrometry, flame AAS. Concentrations of total butyltin (BTs: DBT + TBT) in mussels ranged from 0.49 to $2438 \mathrm{ng} / \mathrm{g}$ wet wt. The concentrations ( $\mu \mathrm{g} / \mathrm{g}$ wet wt) of heavy metals ranged from 0.40 to 3.55 for $\mathrm{Sn}, 9.62$ to 67.03 for $\mathrm{Cu}$, and 87.13 to $731.51 \mathrm{for} \mathrm{Zn}$. Total of tin in mussels ranged from 0.2 to $1054.78 \mathrm{ng} / \mathrm{g}$. Higher concentrations of butyltin compounds were found in mussels collected from Mers El Kebir shipyard, Arzew, a petroleum harbour (industrial), and Beni Saf fishing harbour. This suggested that maritime activities nearby the harbours play a major role as the source of BTs. Indeed, harbour of Arzew is frequented by voluminous tanker. TBT was the predominant compound in mussels collected from almost all the sampling locations; indicate the fresh input of TBT in harbours.
\end{abstract}

Keywords: Organotin; Tin; Copper; Zinc; Mytilus galloprovincialis; GC-MS; AAS

\section{Introduction}

Many biocides have been introduced in antifouling coatings, to prevent marine life from colonizing, yet $\mathrm{Cu}$, in the form of cuprous oxide, continues to be one of the most common components of modern antifouling products, but not necessarily the most effective. Organotins, especially tributyltin (TBT), were first used as booster biocides and has been referred to as the most effective antifouling biocide ever developed. Indeed, Butyltin compounds have been widely used during the last decades as biocides in antifouling paint applied for boats and aquaculture, PVC stabilisers, wood preservatives, in agriculture and in several industrial processes [1-3]. However, their main source in the marine ecosystem is related to their use as antifouling paint biocides. Many researches revealed that leaching of the active antifouling biocides tributyltin (TBT), copper $(\mathrm{Cu})$ and zinc $(\mathrm{Zn})$ or ablation of antifouling paint chips from ships' hulls may expose non-target organisms. Thus, in 2008, the International Maritime Organization approved a complete ban

"Corresponding author. on TBT use. However, given its persistence, TBT can be expected to remain in waters and sediments for long periods of time [4]. Aquatic pollution resulting from their use has been of great interest in many countries due to their bioaccumulative potential and ecotoxicological effects on different aquatic organisms. It has been documented that some molluscs such as oysters [5-7] and gastropods [8-11] are susceptible to toxic effects of tributyltin (TBT). Severe toxic effects of TBT such as shell calcification anomalies in oysters and imposex phenomenon in gastropods occur at low TBT concentrations (1 $\mathrm{ng} / \mathrm{L}$ ) [7-9]. Few micrograms per litre or even lower of TBT have toxic effects on embryonic and early life stages of aquatic organisms $[7,8,12]$. TBT disrupts also the endocrine system in some molluscs, bioaccumulation of organotins decreases aromatase activity leading to a rise in testosterone levels that promotes development of male characteristics $[12,13]$. Consequently and in response to increasing scientific evidence concerning these environmental impacts on non-target organisms, many countries regulate the use of TBT in antifouling paints. The regulations banned the use of these compounds for 
ships smaller than $25 \mathrm{~m}$ in length in many developed countries, such as many European countries, Canada, the United States and Australia, since the 1980s [14]. Organotin compounds degrade in the environment into more polar metabolites [15] and tributyltin one of the most frequently used organotin additives degrades into dibutyltin (DBT) and monobutyltin (MBT). Moreover, TBT and $\mathrm{Cu}$ inhibit the settlement and metamorphosis of some broadcast spawning species of coral larvae at concentrations as low as $2 \mu \mathrm{g} \cdot \mathrm{l}^{-1}$ TBT-chloride $\left(0.73 \mu \mathrm{g} \cdot \mathrm{l}^{-1}\right.$ Sn) [16] and $42 \mu \mathrm{g} \cdot \mathrm{l}^{-1} \mathrm{Cu}$ [17]. TBT, $\mathrm{Cu}$ and $\mathrm{Zn}$ can also reduce the fertilization success of coral gametes $[16,18]$ and cause often physiological, histological, biochemical and enzymatic alterations in fish [19]. Consequently, a large diversity of organotin compounds can be detected in environmental samples [20]. Analytical techniques for the determination of trace amounts of organotin compounds in environmental samples have been reviewed in several papers [21,22]. Gas chromatography (GC) is usually used as a separation technique due to its higher resolving power and the availability of more sensitive and selective detectors, mainly Gas chromatography-mass spectrometry (GC-MS) [23-26].

Most of the organotins need to be derivatized, to convert ionic organotin compounds to more volatile species, before GC separation. The most commonly applied derivatization reactions for organotin analysis are hydride generation with $\mathrm{NaBH}_{4}$, ethylation with $\mathrm{NaBEt}_{4}$ and alkylation with Grignard reagents [27,28].

Bivalves such as mussels, which are epibenthic filter feeder, have been addressed as bioindicators (mussel watch) for monitoring trace toxic substances. Mussels accumulate BTs in direct proportion to the environmental levels $[29,30]$, in coastal waters due to their wide geographic distribution, sessile life style, easy sampling, tolerance to a considerable range of salinity, resistance to stress and high accumulation of a wide range of chemicals [31]. In particular, mussel Mytilus galloprovincialis Lamarck, 1819, which has a wide geographical distribution in the West Mediterranean region, is recognized as commercially valuable seafood.

The aim of this work was to determine the contamination level by butyltin compounds, tin, cuprous and zinc in some West Algerian harbours. Mussels were collected from six sites over a period of 6 months. Gas chromatography combined with electron impact (EI) mass spectrometry GC-MS-EI has been used for structural identification of TBT and DBT in mussel tissues. BTs concentrations in mussel tissues were estimate and their distribution in different sites was discussed. Measurements of $\mathrm{Sn}, \mathrm{Cu}$ and $\mathrm{Zn}$ content were carried out using a PerkinElmer atomic absorption spectrometer.

\section{Materials and Methods}

\subsection{Materials}

Tetra-n-butyltin (TeBT, 98\%), was purchased from Fluka and sodium tetrahydroborate was supplied by Aldrich. Hexane solvent used was analytical-grade quality; it was purchased from Aldrich, and was distilled in a glass still before use. All other chemicals used were of the highest purity materials available from commercial sources and were used without any purification.

\subsection{Instrumentation}

\subsubsection{GC-MS Apparatus}

GC-MS was performed on a Perkin-Elmer Clarus 500 Quadrupole Mass Spectrometer (MS) (EI mode, $70 \mathrm{eV}$ ) interfaced by a direct transfer line to a Clarus 500 Gas Chromatograph (GC). The GC column was a capillary column with a thin, immobilized stationary phase of HP5 MS, 5\% Phényl-95\% diméthylpolysiloxane, $(60 \mathrm{~m} \times 0.25$ $\mathrm{mm}$ I.D., $0.25 \mu \mathrm{m}$ film thickness). A split/splitless injector was used in the split injection mode with an inlet pressure of $50 \mathrm{kPa}$ using helium as the carrier gas. For all analyses, a volume of $1 \mu \mathrm{l}$ of sample was injected. A temperature program was employed in which the column temperature was initially held at $50^{\circ} \mathrm{C}$ for $1 \mathrm{~min}$, then increased at $10^{\circ} \mathrm{C} \cdot \mathrm{min}^{-1}$ to a final temperature of $300^{\circ} \mathrm{C}$, and held for $4 \mathrm{~min}$. The injector temperature was held constant at $250^{\circ} \mathrm{C}$. Organotin species were ionized by using the EI source of the mass spectrometer. Conditions for the mass spectrometer were as follows: GC-MS interface temperature of $220^{\circ} \mathrm{C}$, electron energy of $70 \mathrm{eV}$ and ionizer temperature of $220^{\circ} \mathrm{C}$ for EI mode. Chromatograms were recorded under selected ion monitoring (SIM) and full scan (from $\mathrm{m} / \mathrm{z} 30$ to 500 ) conditions. Three $\mathrm{m} / \mathrm{z}$ values were used for SIM mode for each butyltin compound (DBT 121, 177, 235; TBT 121, 177, 291).

\subsubsection{AAS Apparatus}

Measurements were carried out using a Perkin-Elmer Precisely AA800 atomic absorption spectrometer with an HGA 400 air-acetylene flame and graphite furnace atomiser, AS-93 plus autosampler, deuterium background correction and equipped with WinLab 32 ${ }^{\mathrm{TM}}$ for AA Version 6.5 software, which features all the tools needed to analyze samples. Hollow cathode lamps were used as radiation sources for $\mathrm{Sn}, \mathrm{Cu}$ and $\mathrm{Zn}$ determinations. $\mathrm{Sn}$ was analyzed on a nitrous oxide-acetylene flame and $\mathrm{Cu}$ and $\mathrm{Zn}$ were analyzed on an air-acetylene flame. The main resonance line at $286.3 \mathrm{~nm}$ for $\mathrm{Sn}, 324.8 \mathrm{~nm}$ for $\mathrm{Cu}$ and $213.9 \mathrm{~nm}$ for $\mathrm{Zn}$ were used for all determinations, with a spectral bandwidth of $0.7 \mathrm{~nm}$ for $\mathrm{Sn}, \mathrm{Cu}$ and $\mathrm{Zn}$. 
Perkin Elmer NIST traceable calibration standards in acid for atomic spectroscopy were used as the stock standards for preparing working standards. All the working standards were prepared daily with ASTM type I water acidified in Supra pure nitric acid (Aldrich) in polypropylene vials on volume-by-volume dilution.

\subsection{Samples}

Mussels Mytilus galloprovincialis were collected from six harbour areas of the West of Algeria (Figure 1), during period of December to May (2007-2008). Locations of samples used in these analyses are indicated in Table 1. Fifty mussels of $40-80 \mathrm{~mm}$ shell length were collected at each location and adhering matrix was removed in the field. Samples were stored in polyethylene bags, kept in a cooler box with ice or dry ice and then immediately kept in a deep freezer. The frozen mussel samples were subsequently transported to the laboratory, thawed, scraped cleaned and shucked. The whole soft tissues were pooled, homogenized, transferred to glass bottles and then frozen at $-20^{\circ} \mathrm{C}$ until chemical analysis.

\subsection{Chemical Analysis}

All the glassware used for the analysis of the samples was cleaned carefully to avoid contamination. Briefly, all the glassware was soaked in 5\% nitric acid solution for $24 \mathrm{~h}$ and washed with distilled water followed and dried in an electrical oven.

The analytical method of BTs was conducted based on the procedure, simultaneous extraction into hexane and hydridization by $\mathrm{NaBH}_{4}$, previously described [32-36], with, however, some light changes. The analytical protocol consists of two steps:

First step: four tubes for centrifugation are used, in each one, puts $5 \mathrm{~g}$ of pooled tissues. The mixture of each tube was extracted with $20 \mathrm{ml}$ of $\mathrm{HCl} 2 \mathrm{~N}$ (centrifugation with $2500 \mathrm{rpm}$ during $10 \mathrm{mn}$ ). The supernatant liquid was recovered in a clean erlen. The process of extraction is repeated twice under the same conditions.

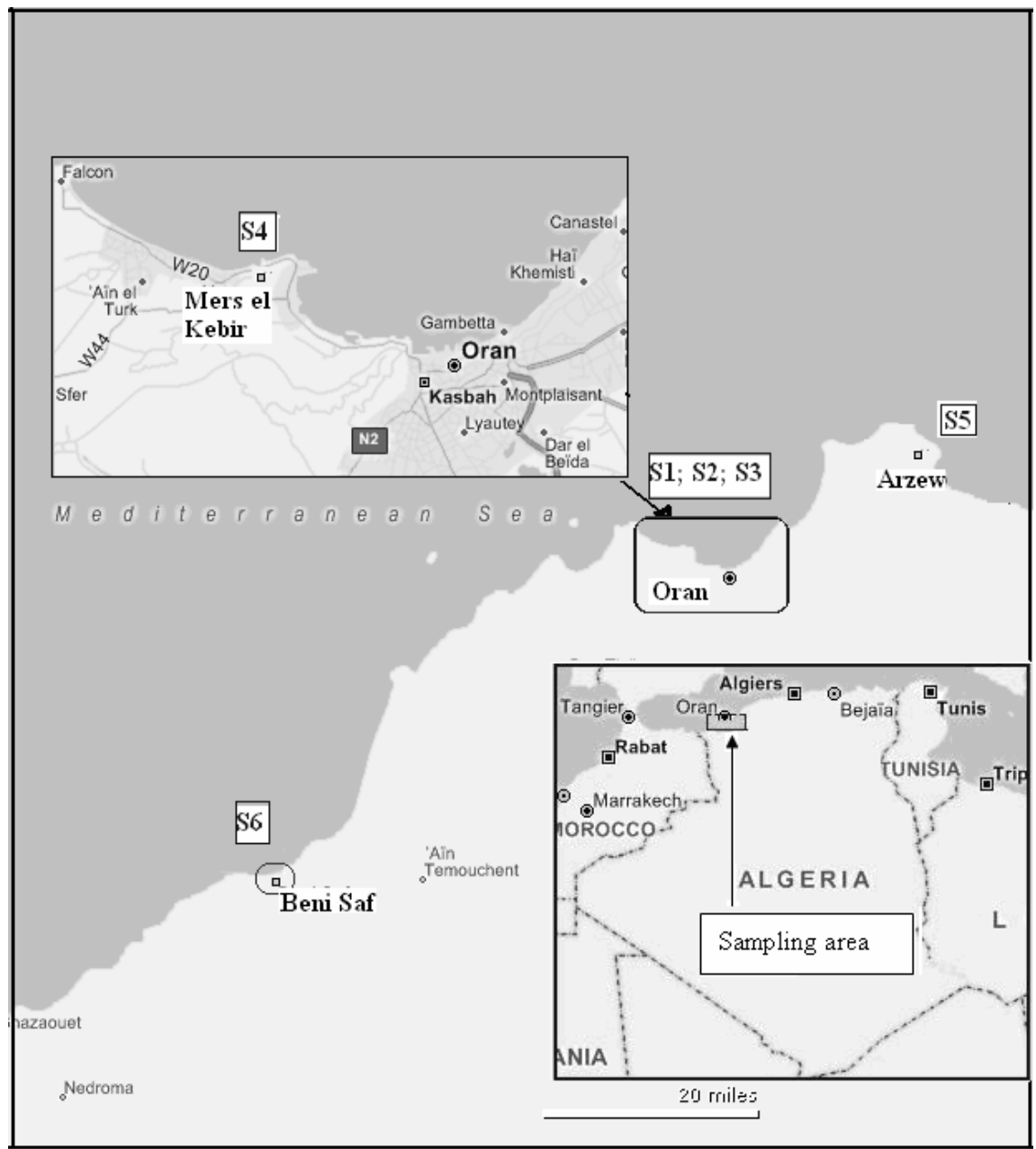

Figure 1. Map showing the sampling locations of mussels (Mytilus galloprovincialis) in West Algeria. 
Table 1. Sampling locations of mussel.

\begin{tabular}{cccc}
\hline Harbour sites & Locations & Latitude north & Longitude west \\
\hline \multirow{2}{*}{ Oran } & S1: Sector 1 & $35^{\circ} 42^{\prime}$ & $0^{\circ} 38^{\prime}$ \\
& S2: fishery & $35^{\circ} 43^{\prime}$ & $0^{\circ} 38^{\prime}$ \\
& $\begin{array}{c}\text { S3: Mouth of } \\
\text { harbour }\end{array}$ & $35^{\circ} 42^{\prime}$ & $0^{\circ} 38^{\prime}$ \\
Mers El Kebir & S4: shipyard & $35^{\circ} 44^{\prime}$ & $0^{\circ} 42^{\prime}$ \\
Arzew & S5: harbour & $35^{\circ} 51^{\prime}$ & $0^{\circ} 18^{\prime}$ \\
Beni Saf & S6: fishery & $35^{\circ} 18^{\prime}$ & $1^{\circ} 23^{\prime}$ \\
\hline
\end{tabular}

Second step: The supernatant liquid was adjusted with bidistilled water to $500 \mathrm{ml}$ and to $\mathrm{pH} 5$ with sodium acetate. The organotin compounds were hydritized directly in aqueous phase by sodium borohydrure and extracted with $50 \mathrm{ml}$ hexane under vigorous shaking for $10 \mathrm{~min}$. The extracts were decanted; another $20 \mathrm{ml}$ of hexane was added to the original homogenate, and the mixture was again shaken for $10 \mathrm{~min}$. The combined extract was dried with $\mathrm{Na}_{2} \mathrm{SO}_{4}$ and concentrated on a rotary evaporator to about 1 - $2 \mathrm{ml}$. The final volume was adjusted to $1.0 \mathrm{ml}$ under a gentle stream of pure nitrogen, mixed with a suitable amount $(1 \mu \mathrm{g})$ of standard TeBT and directly analyzed by gas chromatography. Finally, the aqueous phase was analyzed by atomic absorption spectrometer (AAS) to determine $\mathrm{Cu}$ and $\mathrm{Zn}$ content.

\section{Results and Discussion}

\subsection{Organotin Determination}

Separation of the organotin compounds was performed on a standard HP-5MS capillary column.

The sample chosen for the study of BTs identification is that of the Beni Saf's fishery, which is very frequented by tankers. The different ions fragments of TBT and DBT are given in Table 2, masses are calculated for the ${ }^{120} \mathrm{Sn}$ isotope. The most abundant ions appear in $\mathrm{M}-114$ for the TBT and M-59 for the DBT, with a loss respecttively of two and one butyl fragments and the molecular ion $\mathrm{M}^{+}$appear at 292. Plzák et al. [23], obtained similar results.

The abundance distributions of TBT and DBT in mussel tissues, found in all sites and calculated from surfaces of the peaks, using TeBT as standard, are shown in Table 3. Results show well that all the analyzed sites are contaminated by BTS.

Table 3 shows the existence of contamination of the mussels by TBT practically in all sampled locations. The profiles are marked by peaks of concentration with a very clear preponderance of the TBT whose concentration reaches a maximum for the site of Mers El Kebir (1896
Table 2. Comparison of theoretical and observed masses for major ions in EI ionization mode.

\begin{tabular}{ccccc}
\hline $\begin{array}{c}\text { Compound } \\
(\mathbf{M})\end{array}$ & Fragment & $\begin{array}{c}\text { Expected } \\
\text { ion }\end{array}$ & $\begin{array}{c}\text { Calculated } \\
\text { mass }\end{array}$ & $\begin{array}{c}\text { Observed } \\
\text { mass }\end{array}$ \\
\hline & $\left(\mathrm{C}_{4} \mathrm{H}_{9}\right)_{3} \mathrm{SnH}$ & {$[\mathrm{M}]^{+}$} & 292 & 292 \\
& $\left(\mathrm{C}_{4} \mathrm{H}_{9}\right)_{3} \mathrm{Sn}$ & {$[\mathrm{M}-1]^{+}$} & 291 & 291 \\
$\begin{array}{c}\left(\mathrm{C}_{4} \mathrm{H}_{9}\right)_{3} \mathrm{SnH} \\
(292)\end{array}$ & $\left(\mathrm{C}_{4} \mathrm{H}_{9}\right)_{2} \mathrm{SnH}$ & {$[\mathrm{M}-57]^{+}$} & 235 & 235 \\
& $\mathrm{C}_{4} \mathrm{H}_{9} \mathrm{SnH}$ & {$[\mathrm{M}-114]^{+}$} & 178 & 177 \\
& $\mathrm{SnH}$ & {$[\mathrm{M}-171]^{+}$} & 121 & 121 \\
& $\left(\mathrm{C}_{4} \mathrm{H}_{9}\right)_{2} \mathrm{SnH} \mathrm{H}_{2}$ & {$[\mathrm{M}]^{+}$} & 236 & 236 \\
$\left(\mathrm{C}_{4} \mathrm{H}_{9}\right)_{2} \mathrm{SnH}_{2}$ & $\left(\mathrm{C}_{4} \mathrm{H}_{9}\right)_{2} \mathrm{SnH}$ & {$[\mathrm{M}-1]^{+}$} & 235 & 235 \\
$(236)$ & $\mathrm{C}_{4} \mathrm{H}_{9} \mathrm{Sn}$ & {$[\mathrm{M}-59]^{+}$} & 177 & 177 \\
& $\mathrm{SnH}$ & {$[\mathrm{M}-115]^{+}$} & 121 & 121 \\
\hline
\end{tabular}

Table 3. Concentrations of butyltin compounds (ng/g wet wt) in the various analyzed matrices.

\begin{tabular}{ccccc}
\hline & TBT & DBT & $\Sigma$ BTs & Total tin \\
\hline Arzew's harbour & $1116 \pm 15$ & $1099 \pm 23$ & 2215 & 1017.45 \\
Beni Saf's fishery & $1353 \pm 18$ & $679 \pm 16$ & 2032 & 901.28 \\
$\begin{array}{c}\text { Mers El Kébir's } \\
\text { shipyard }\end{array}$ & $1896 \pm 22$ & $542 \pm 13$ & 2438 & 1054.78 \\
$\begin{array}{c}\text { Mouth of Oran's } \\
\text { harbour } \\
\begin{array}{c}\text { Oran's harbour } \\
\text { (sector 1) }\end{array}\end{array}$ & $665 \pm 6$ & $44 \pm 7$ & 709 & 295.66 \\
$\begin{array}{c}\text { Oran's fishery } \\
\text { Oran }\end{array}$ & $0.49 \pm 0.0$ & $2.61 \pm 0.6$ & 5.39 & 2.47 \\
\hline
\end{tabular}

$\mathrm{ng} / \mathrm{g}$ ). The highest concentration was thus found in mussels coming from the Mers El Kébir harbour. This result is in agreement with the sampling which was done in the shipyard where is made the ship building and maintenance, or scouring, of the ship hulls and where a great quantity of toxic coatings, primarily made up of antifouling paints based on TBT, is thrown directly at sea. On the other hand, abundance in TBT compared to the DBT $(542 \mathrm{ng} / \mathrm{g})$, approximately four times more, suppose that the TBT was recently introduced and/or slightly degraded. Observation confirmed by Bhosle et al. [37] which found similar results on the west coast of India.

The second location, more polluted in TBT is that of the harbour of Arzew (1116 ng/g), this is due to a great frequentation of this harbour by tankers which use paintings containing TBT and which come from various areas of the world. In this site the TBT concentration is almost identical to that of the DBT $(1099 \mathrm{ng} / \mathrm{g})$; this is explained by equilibrium between the speed of TBT release and its speed of degradation. 
The following site is that of the Beni Saf's fishery, it is a small fishing port with a great concentration in the trawlers.

Moreover, the antifouling paint, used by these trawlers, is primarily based on TBTO. The TBT concentration $(1353 \mathrm{ng} / \mathrm{g})$ is twice higher than that in DBT $(679 \mathrm{ng} / \mathrm{g})$, although the port of Beni Saf is loaded with organic matters (worn water discharge of the municipality) facilitateing the degradation of the TBT, this is due to a fresh introduction of this last.

The three sites of Oran, first is located at the mouth of the port, it is an opened site, which explains its weak TBT concentration $(665 \mathrm{ng} / \mathrm{g})$ compared to the three first. At last, for the last two sites, the weak TBT concentration $(2.78$ and $0.49 \mathrm{ng} / \mathrm{g})$ is explained by the fact that in the Sector 1, where is made the maintenance of the tug boats, a free TBT paint is used, and in the fishery is used a antifouling paint based on copper, except for some rare trawlers.

\subsection{Tin, $\mathrm{Cu}$ and Zinc Determination}

The $\mathrm{Sn}, \mathrm{Cu}$ and $\mathrm{Zn}$ concentrations found in the samples, collected at the stations shown in Figure $\mathbf{1}$ and using the sample preparation and analytical methods described above, were $0.40-3.55 \mu \mathrm{g} \cdot \mathrm{g}^{-1} \mathrm{Sn}, 9.62-67.03 \mu \mathrm{g} \cdot \mathrm{g}^{-1} \mathrm{Cu}$ and $87.13-731.51 \mu \mathrm{g} \cdot \mathrm{g}^{-1} \mathrm{Zn}$. The metals distribution is shown in Table 4.

\subsubsection{Tin Determination}

The concentration of Sn measured implies that traces of old, organotin-based formulations may also have been present. Indeed, the degradation of organotin compounds occurs by biotic or abiotic processes, the transformation is similar for both cases and leads via subsequent dealkylation or dearylation to inorganic tin, as shown in Scheme 1 [38].

Consequently, the SAA results showed that the highest concentrations of Sn are respectively in the Beni Saf's

Table 4. Concentration values obtained for mussel at the sampling stations.

\begin{tabular}{|c|c|c|c|}
\hline Site & $\mathrm{Sn}(\mu \mathrm{g} / \mathrm{g})$ & $\mathrm{Cu}(\mu \mathrm{g} / \mathrm{g})$ & $\mathrm{Zn}(\mu \mathrm{g} / \mathrm{g})$ \\
\hline Beni Saf's port & $3.55 \pm 0.451$ & $14.91 \pm 0.81$ & $090.33 \pm 3.93$ \\
\hline Harbour of Arzew & $3.09 \pm 0.421$ & $13.22 \pm 0.76$ & $125.45 \pm 5.35$ \\
\hline $\begin{array}{l}\text { Mers El Kebir's } \\
\text { shipyard }\end{array}$ & $2.13 \pm 0.252$ & $09.62 \pm 0,15$ & $087.13 \pm 03.40$ \\
\hline $\begin{array}{l}\text { Oran' port: } \\
\text { sector } 1\end{array}$ & $0.78 \pm 0.032$ & $19.72 \pm 1.32$ & $385.53 \pm 12.75$ \\
\hline $\begin{array}{l}\text { Oran' Port: mouth } \\
\text { of harbour }\end{array}$ & - & $14.11 \pm 0.81$ & $139.14 \pm 5.37$ \\
\hline Oran's fishery & $0.40 \pm 0.012$ & $67.03 \pm 2.36$ & $731.51 \pm 23.7$ \\
\hline
\end{tabular}

fishery $(3.55 \mu \mathrm{g} / \mathrm{g})$, the harbour of Arzew $(3.09 \mu \mathrm{g} / \mathrm{g})$ and the site of Mers El Kebir $(2.13 \mu \mathrm{g} / \mathrm{g})$, and decrease toward the Oran's fishery $(0.40 \mu \mathrm{g} / \mathrm{g})$. The concentration in the mouth of the port was not detected. Results are in agreement with GC-MS results. Indeed, the port of Beni Saf is loaded with high quantity of organic matters, resulting from the sewage effluents of urban influence discharge, contributing to increase the degradation of organotin compounds. Total tin concentrations, from GCMS and SAA results, are showed in Table 5.

\subsection{2. $\mathrm{Cu}$ and $\mathrm{Zn}$ Determination}

Trace metals, especially copper and zinc, are commonly occurring contaminants in harbours and marinas. One source of copper to these environs is copper-based antifouling coatings used on vessel hulls. $\mathrm{Cu}$ and $\mathrm{Zn}$ were associateted with the principal biocidal pigments $\left(\mathrm{Cu}_{2} \mathrm{O}\right.$, $\mathrm{CuCNS}$ and $\mathrm{ZnO}$ ). Other sources of high abundance of heavy metals, especially $\mathrm{Cu}$ and $\mathrm{Zn}$, are their use in the construction of water pipelines and other reservoirs metals. These metals may dissolve and become incorporated in the urban sewage effluents as showed by Phillips et al. [39].

The $\mathrm{Cu}$ and $\mathrm{Zn}$ distribution is shown in Table 4. The highest concentrations of $\mathrm{Cu}(67.03 \mu \mathrm{g} / \mathrm{g})$ and $\mathrm{Zn}(731.51$ $\mu \mathrm{g} / \mathrm{g}$ ) are in the Oran's fishery, these results are in agreement with GC-MS results. These concentrations show that the antifouling paint used by marine trawlers is a free TBT paint and generally based on copper.

\section{Conclusion}

Biocides incorporated in antifouling formulations, particularly butyltin compounds and copper, are among the most potent androgenic compounds ever added to the

$$
\begin{gathered}
\mathrm{R}_{4} \mathrm{Sn} \rightarrow \underset{\left(\mathrm{R}=\mathrm{C}_{4} \mathrm{SnX} \rightarrow \mathrm{R}_{9}-\mathrm{SnX}_{2} \rightarrow \mathrm{CrSnX}_{5} \mathrm{H}_{6}-\right.\text { and }}{(\mathrm{R}=\mathrm{Sn}} \\
\mathrm{X}=\text { chloride, fluoride, oxides and phosphates })
\end{gathered}
$$

Scheme 1. Degradation of organotin compounds.

Table 5. Total tin concentrations (ng/g) from GC-MS and SAA analysis.

\begin{tabular}{lccc}
\hline Site & GC-MS results & SAA results & Total tin \\
\hline Beni Saf's port & 1017.45 & 3548 & 4565.45 \\
Harbour of Arzew & 901.28 & 3092 & 3993.28 \\
$\begin{array}{l}\text { Mers El Kebir's } \\
\text { shipyard }\end{array}$ & 1054.78 & 2128 & 3182.78 \\
$\begin{array}{l}\text { Oran' port: sector 1 } \\
\begin{array}{l}\text { Oran' port: mouth } \\
\text { of harbour }\end{array}\end{array}$ & 295.66 & 777 & 1072.66 \\
Oran's fishery & 2.47 & - & 2.47 \\
\hline
\end{tabular}


environment. Their analysis in the marine environment is essential because of their toxicity, the regulations concerning their use and their impact on the economy. The results obtained show well that the Algerian harbours are not free from contamination by copper and organotin compounds, particularly the TBT, of which the toxic effects on the aquatic environment are well-known. TBT and DBT, although estimated, were detected in substantial amounts in mussel tissues collected from the various locations along the west coast of Algeria. These results indicate possible toxic/genotoxic effects on marine organisms at investigated sites, with direct implications for the shell fishery and human risk/health. These preliminary data suggest that the study area is contaminated with TBT and copper, thus there is a need for more detailed investigations with more number of samples to elucidate distribution, source and bioaccumulation and toxic effects in this area.

\section{Acknowledgements}

Authors are grateful to Mr. M. Benabdessalem, Mr A. Cherifi members of the Oran's scientific laboratory, and all equip of the laboratory for their support and for their advice on the analysis of TBT compounds and heavy metals. We also thank Pr. M. Belbachir, the Director of the Chemistry Laboratory of Polymers for its cordial reception in the laboratory.

\section{REFERENCES}

[1] C. J. Evans and S. Karpel, "Organotins Compounds in Modern Technology,” Elsevier, Amsterdam, 1985.

[2] R. J. Maguire, "Review: Environmental Aspects of Tributyltin," Applied Organometallic Chemistry, Vol. 1, No. 6, 1987, pp. 475-498. doi:10.1002/aoc.590010602

[3] H. Rudel, "Case Study: Bioavailability of Tin and Tin Compounds," Ecotoxicology and Environmental Safety, Vol. 56, No. 1, 2003, pp. 180-189. doi:10.1016/S0147-6513(03)00061-7

[4] A. Sousa, C. Matsudaira, S. Takahashi, S. Tanabe and C. Barroso, "Integrative Assessment of Organotin Contamination in a Southern European Estuarine System (Ria de Aveiro, NW Portugal): Tracking Temporal Trends in Order to Evaluate the Effectiveness of the EU Ban," Marine Pollution Bulletin, Vol. 54, No. 10, 2007, pp. 1645-1653. doi:10.1016/j.marpolbul.2007.07.005

[5] C. Alzieu, M. Héral, Y. Thibaud, M. J. Dardignac and M. Feuillet, "Influence des Peintures Antisalissures à Base d'Organstanniques sur la Calcification de la Coquille d'Huître C. gigas," Revue des Travaux de l'Institut des Pêches Maritimes, Vol. 45, No. 2, 1981, pp. 101-116.

[6] C. Alzieu, J. Sanjuan, J.-P. Deltreiland and M. Borel, "Tin Contamination in Arcachon Bay: Effects on Oyster Shells Anomalies," Marine Pollution Bulletin, Vol. 17, No. 11, 1986, pp. 494-498. doi:10.1016/0025-326X(86)90636-3
[7] C. Alzieu, "Biological Effects of Tributyltin on Marine Organisms,” In: S. J. De Mora, Ed., Dans Tributylti: Case Study of an Environmental Contaminant, Cambridge University Press, Cambridge, 1996, pp. 167-211. doi:10.1017/CBO9780511759772.007

[8] G. W. Bryan and P. E. Gibbs, "Impact of Low Concentrations of Tributyltin (TBT) on Marine Organisms: A Review," In: M. C. Newman and A. W. McIntosh, Eds., Metal Ecotoxicology, Concepts and Applications, Lewis Publishers, Chelsea, 1991.

[9] P. E. Gibbs and G. W. Bryan, "TBT-Induced Imposex in Neogastropos Snail: Masculinization to Mass Extinction," In: S. J. de Mora, Ed., Tributyltin: Case Study of an Environmental Contaminant, Cambridge University Press, Cambridge, 1996, pp. 212-276. doi:10.1017/CBO9780511759772.008

[10] T. Horiguchi and H. Shiraishi, "Imposex in Sea Snails, Caused by Organotin (Tributyltin and Triphenyltin) Pollution in Japan: A Survey," Applied Organometallic Chemistry, Vol. 11, No. 5, 1997, pp. 451-455. doi:10.1002/(SICI)1099-0739(199705)11:5<451::AID-A OC598>3.0.CO;2-\#

[11] M. M. Santos, M. A. Reis-Henriques, M. N. Vieira and M. Solé, "Triphenyltin and Tributyltin, Single and in Combination, Promote Imposex in the Gastropod Bolinus brandaris," Ecotoxicology and Environmental Safety, Vol. 64, No. 2, 2006, pp. 155-162. doi:10.1016/j.ecoenv.2005.02.003

[12] K. Fent, "Ecotoxicology of Organotin Compounds," Critical Reviews in Toxicology, Vol. 26, No. 1, 1996, pp. 1117. doi:10.1016/j.ecoenv.2005.02.003

[13] F. Grün, H. Watanabe, Z. Zamanian, L. Maeda, K. Arima, R. Cubacha, D. M. Gardiner, J. Kanno, T. Iguchi and B. Blumberg, "Endocrine-Disrupting Organotin Compounds Are Potent Inducers of Adipogenesis in Vertebrates," Molecular Endocrinology, Vol. 26, No. 2, 2006, pp. 2141-2155. doi:10.1210/me.2005-0367

[14] C. Stewart, "The Efficiency of Legislation in Controlling Tributyltin in the Marine Environment," In: S. J. de Mora Ed., Tributytltin: Case Study of an Environmental Contaminant, Cambridge University Press, Cambridge, 1996, pp. 264-297. doi:10.1017/CBO9780511759772.010

[15] P. J. Graig, "Organometallics in the Environment: Principles and Reactions," Longman, Harlow, 1986, p. 133.

[16] A. P. Negri and A. J. Heyward, "Inhibition of Coral Fertilization and Larval Metamorphosis Bytributyltin and Copper," Marine Environmental Research, Vol. 51, No. 1, 2001, pp. 17-27. doi:10.1016/S0141-1136(00)00029-5

[17] A. J. Reichelt-Brushett and P. L. Harrison, "The Effect of Copper on the Settlement Success of Larvae from the Scleractinian Coral Acropora tenuis," Marine Pollution Bulletin, Vol. 41, No. 7-12, 2000, pp. 385-391. doi:10.1016/S0141-1136(00)00029-5

[18] A. J. Reichelt-Brushett and P. L. Harrison, "The Effect of Copper, Zinc and Cadmium on Fertilization Success of Gametes from Scleractinian Reef Corals," Marine Pollution Bulletin, Vol. 38, No. 3, 1999, pp. 182-187. doi:10.1016/S0025-326X(98)00183-0 
[19] A. Safahieh, F. A. Monikh, A. Savari and A. Doraghi, "Heavy Metals Concentration in Mullet Fish, Liza abu from Petrochemical Waste Receiving Creeks, Musa Estuary (Persian Gulf)," Journal of Environmental Protection, Vol. 2, No. 9, 2011, pp. 1218-1226. doi:10.4236/jep. 2011.29140

[20] H. Harino, M. Fukushima, Y. Yamamoto, S. Kawai and N. Miyazaki, "Organotin Compounds in Water, Sediment, and Biological Samples from the Port of Osaka, Japan," Archives of Environmental Contamination and Toxicology, Vol. 35, No. 4, 1998, pp. 558-564. doi:10.1007/s002449900416

[21] P. Quevauviller, M. Astruc, R. Morabito, F. Ariese and L. Ebdon, "Collaborative Evaluation of Methods for Tributyltin Determinations in Sediment and Mussel Tissue," TrAC Trends in Analytical Chemistry, Vol. 19, No. 2-3, 2000, pp. 180-188. doi:10.1016/S0165-9936(99)00203-4

[22] Z.-H. Yu, J.-Q. Sun, M. Jing, X. Cao, F. Lee and X.-R. Wang, "Determination of Total Tin and Organotin Compounds in Shellfish by ICP-MS," Food Chemistry, Vol. 119, No. 1, 2010, pp. 364-367. doi:10.1016/j.foodchem.2009.05.079

[23] Z. Plzak, M. Polanská and M. Suchánek, "Identification and Determination of Butyltin Compounds in Water by Ion Trap Gas Chromatography-Mass Spectrometry after Conversion to Methyl or Hydride Derivatives," Journal of Chromatography A, Vol. 699, No. 1-2, 1995, pp. 241252. doi:10.1016/0021-9673(95)00071-T

[24] C.-C. Chou and M.-R. Lee, "Determination of Organotin Compounds in Water by Headspace Solid Phase MicroExtraction with Gas Chromatography-Mass Spectrometry," Journal of Chromatography A, Vol. 1064, No. 1, 2005, pp. 1-8. doi:10.1016/j.chroma.2004.08.166

[25] C. Devos, M. Vliegen, B. Willaert, F. David, L. Moens and P. Sandra, "Automated Headspace-Solid-Phase Micro Extraction-Retention Time Locked-Isotope Dilution Gas Chromatography-Mass Spectrometry for the Analysis of Organotin Compounds in Water and Sediment Samples," Journal of Chromatography A, Vol. 1079, No. 1-2, 2005, pp. 408-414. doi:10.1016/j.chroma.2004.12.020

[26] M. Üveges, P. Rodríguez-González, J. I. García, Alonso, A. Sanz-Medel and P. Fodor, "Isotope Dilution Analysis Mass Spectrometry for the Routine Measurement of $\mathrm{Bu}-$ tyltin Compounds in Marine Environmental and Biological Samples," Microchemical Journal, Vol. 85, No. 1, 2007, pp. 115-121. doi:10.1016/j.microc.2006.04.003

[27] J. Ashby, S. Clark and P. J. Craig, "Methods for the Production of Volatile Organometallic Derivatives for Application to the Analysis of Environmental Samples," Journal of Analytical Atomic Spectrometry, Vol. 3, No. 5, 1988, pp. 735-736. doi:10.1039/ja9880300735

[28] R. Morabito, P. Massanisso and P. Quevauviller, "Derivatization Methods for the Determination of Organotin
Compounds in Environmental Samples," TrAC Trends in Analytical Chemistry, Vol. 19, No. 2-3, 2000, pp. 113119. doi:10.1016/S0165-9936(99)00196-X

[29] H. Harino, S. C. M. O’Hara, G. R. Burt, B. S. Chesman and W. J. Langston, "Distribution of Organotin Compounds in Tissues of Mussels Mytilus edulis and Clams Mya arenaria," Chemosphere, Vol. 58, No. 7, 2005, pp. 877-881. doi:10.1016/i.chemosphere.2004.10.012

[30] C.-H. Tang, C.-H. Hsu and W.-H. Wang, "Butyltin Accumulation in Marine Bivalves under Field Conditions in 2010, pp. 125-132. doi:10.1016/j.marenvres.2010.03.011

[31] E. D. Goldberg, “The Mussel Watch," Marine Pollution Bulletin, Vol. 6, No. 7, 1975, pp. 111-113. doi:10.1016/0025-326X(75)90271-4

[32] H. Iwata, S. Tanabe, T. Mizuno and R. Tatsukawa, "High Accumulation of Toxic Butyltins in Marine Mammals from Japanese Coastal Waters," Environmental Science \& Technology, Vol. 29, No. 12, 1995, pp. 2959-2962. doi:10.1021/es00012a011

[33] J. A. Stäb, M. Frenay, L. L. Freriks, U. A. T. H. Brinkman and W. P. Cofino, "Survey of Nine Organotin Compounds in the Netherlands Using the Zebra Mussel (Dreissena Polymorpha) as Biomonitor," Environmental Toxicology and Chemistry, Vol. 14, No. 12, 1995, pp. 2023-2032.

[34] L. Regoli, H. M. Chan and Y. de Lafontaine, "Organotins in Zebra Mussels (Dreissena Polymorpha) in the St. Lawrence River," Journal of Great Lakes Research, Vol. 25, No. 4, 1999, pp. 839-846. doi:10.1021/es00012a011

[35] J. Strand and G. Asmund, "Tributyltin Accumulation and Effects in Marine Molluscs from West Greenland," Environmental Pollution, Vol. 123, No. 1, 2003, pp. 31-37. doi:10.1016/S0269-7491(02)00361-5

[36] M. A. Shreadah, T. O. Said, S. A. Abd El Ghani and A. M. Ahmed, "Distribution of Different Organotin and Organolead Compounds in Sediment of Suez Gulf," Journal of Environmental Protection, Vol. 2, No. 5, 2011, pp. 545-554. doi:10.4236/jep.2011.25063

[37] N. B. Bhosle, A. Garg, S. Jadhav, R. Harjee, S. S. Sawant, K. Venkat and A. C. Anil, "Butyltins in Water, Biofilm, Animals and Sediments of the West Coast of India," Chemosphere, Vol. 57, No. 8, 2004, pp. 897-907. doi:10.1016/i.chemosphere.2004.06.037

[38] R. J. Maguire, R. J. Tkacz, Y. K. Chau, G. A. Bengert and P. T. S. Wong, "Occurrence of Organotin Compounds in Water and Sediment in Canada," Chemosphere, Vol. 15, No. 3, 1986, pp. 253-274. doi:10.1016/0045-6535(86)90020-2

[39] D. J. H. Phillips, B. J. Richardson, A. P. Murray and J. G. Fabris, "Trace Metals, Organochlorines and Hydrocarbons in Port Phillip Bay, Victoria: A Historical Review," Marine Pollution Bulletin, Vol. 25, No. 5-8, 1992, pp. 200-217. doi:10.1016/0025-326X(92)90226-V 